\title{
Geologia e arcabouço estrutural da Sequência Metavulcanossedimentar Urandi, Bahia
}

\author{
Geology and structural framework of the Urandi \\ Metavolcanosedimentary Sequence, Bahia
}

\author{
Bruno Santos Figueiredo ${ }^{1}$, Simone Cerqueira Pereira Cruz ${ }^{2 *}$, \\ Paulo Alexandre Ribeiro ${ }^{3}$, André Fleck ${ }^{3}$
}

\begin{abstract}
RESUMO: A Sequência Metavulcanossedimentar Urandi (SMU) encontra-se na porção setentrional do Orógeno Araçuaí, tendo como embasamento as rochas do Complexo Santa Isabel. Essa unidade representa uma das sequências metavulcanossedimentares da porção sul do Bloco Gavião. No mapeamento geológico realizado na escala 1:2.000, foram identificados metabasaltos anfibolitizados, itabiritos, metapelitos, queluzitos, mármores, calcissilicáticas e quartzitos. O levantamento estrutural permitiu caracterizar três fases deformacionais compressionais: $\mathrm{D}_{\mathrm{n}}$; $\mathrm{D}_{\mathrm{n}+1}$ (está dividida em $\mathrm{D}_{\mathrm{n}+1}$, e $\mathrm{D}_{\mathrm{n+1}+1}$ ), que foram nucleadas sob um campo de tensôes E-W a NE-SE; e $D_{n+2}$, cujas estruturas refletem o campo de tensão WSW-ENE. As duas fases mais antigas possivelmente estão relacionadas com deformaçóes de idade Riaciana-Orosiriana, ao passo que a última fase deformacional reflete as interaçôes entre substrato do Aulacógeno do Paramirim com o Orógeno Araçuaí. As paragêneses minerais sugerem condiçóes de fácies anfibolito para as duas primeiras fases e xisto verde para a última.
\end{abstract}

PALAVRAS-CHAVE: Sequência Metavulcanossedimentar Urandi; Bloco Gaviāo; cráton; orógeno.

\begin{abstract}
The Urandi Metavolcanosedimentary Sequence (UMS) is located in the northern portion of the Araçuai Orogen. Its basement consists of rocks from the Santa Isabel Complex. This unit represents one of the metavolcanosedimentary sequences of the southern portion of the Gaviāo Block. The geological mapping, performed on a scale of 1:2,000, allowed the identification of amphibolitic metabasalts, itabirites, metapelites, queluzites, marbles, calcic-silicate rocks and quartzites. The structural survey allowed the identification of three deformational and compressional stages: $D_{n} ; D_{n+1}$ (divided into $D_{n+1}$, and $D_{1,1}$, which were nucleated under an $E-W$ to $N E-S E$ orientated stress field; and $D_{n+2}$, whose structures reflect a WSW-ENE orientated stress field. The two most ancient stages are possibly related to the deformations of Rhyacian-Orosirian age, while the last deformational stage reflects the interactions between the substrate from the Paramirim Aulacogen and the Araçuai Orogen. The mineral paragenesis that was observed suggests amphibolite facies condition for the first two stages and greenschist for the last one.
\end{abstract}

KEYWORDS: Urandi Metavolcanosedimentary Sequence; Gaviāo Block; craton; orogen.

\footnotetext{
${ }^{1}$ Departamento de Geologia, Instituto de Geociências, Universidade Federal da Bahia - UFBA, Salvador (BA), Brasil. E-mail:brunos_f@yahoo.com.br ${ }^{2}$ Programa de Pesquisa e Pós-Graduação em Geologia, Centro de Pesquisa em Geofísica e Geologia, Departamento de Geologia, Instituto de Geociências, Universidade Federal da Bahia - UFBA, Salvador (BA), Brasil. E-mail: simonecruzufba@gmail.com

${ }^{3}$ Bahia Mineração - BAMIN, Salvador (BA), Brasil.E-mails: paulo.alexandre@bahiamineracao.com, andre.fleck@bamin.com.br

*Autor correspondente

Manuscrito ID 28623. Recebido em: 22/08/2012. Aprovado em: 29/04/2013
} 


\section{INTRODUÇÃO}

A Sequência Metavulcanossedimentar Urandi (SMU) (Figueiredo 2009) aflora na porção setentrional do Orógeno Araçuaí (Fig. 1) (Pedrosa Soares, Alkmim \& Noce 2007), na zona de interação do Aulacógeno do Paramirim, e do seu embasamento, com esse orógeno (Cruz \& Alkmim 2006). Essa unidade, de idade ainda não definida, integra o contexto regional das sequências metavulcanossedimentares do setor meridional do Bloco Gavião (Barbosa \& Sabaté 2002) e afloram na porção invertida do Aulacógeno, denominada de Corredor do
Paramirim (sensu Alkmim, Brito Neves \& Alves 1993). O significado tectônico e a história evolutiva dessas sequências ainda não foram totalmente esclarecidos. A SMU compreende metavulcânicas máficas, metapelitos, rochas calcissilicáticas, queluzitos, quartzitos e formaçōes ferríferas bandadas (Figueiredo 2009) que foram deformadas e metamorfisadas na fácies anfibolito juntamente com o seu substrato, o Complexo Santa Isabel (Barbosa \& Moutinho da Costa, 1973). Essas unidades são intrudidas por granitoides do Riaciano-Orosiriano (Rosa et al. 1996, Rosa 1999). Embora mereça destaque como hospedeira de importantes depósitos de ferro, a

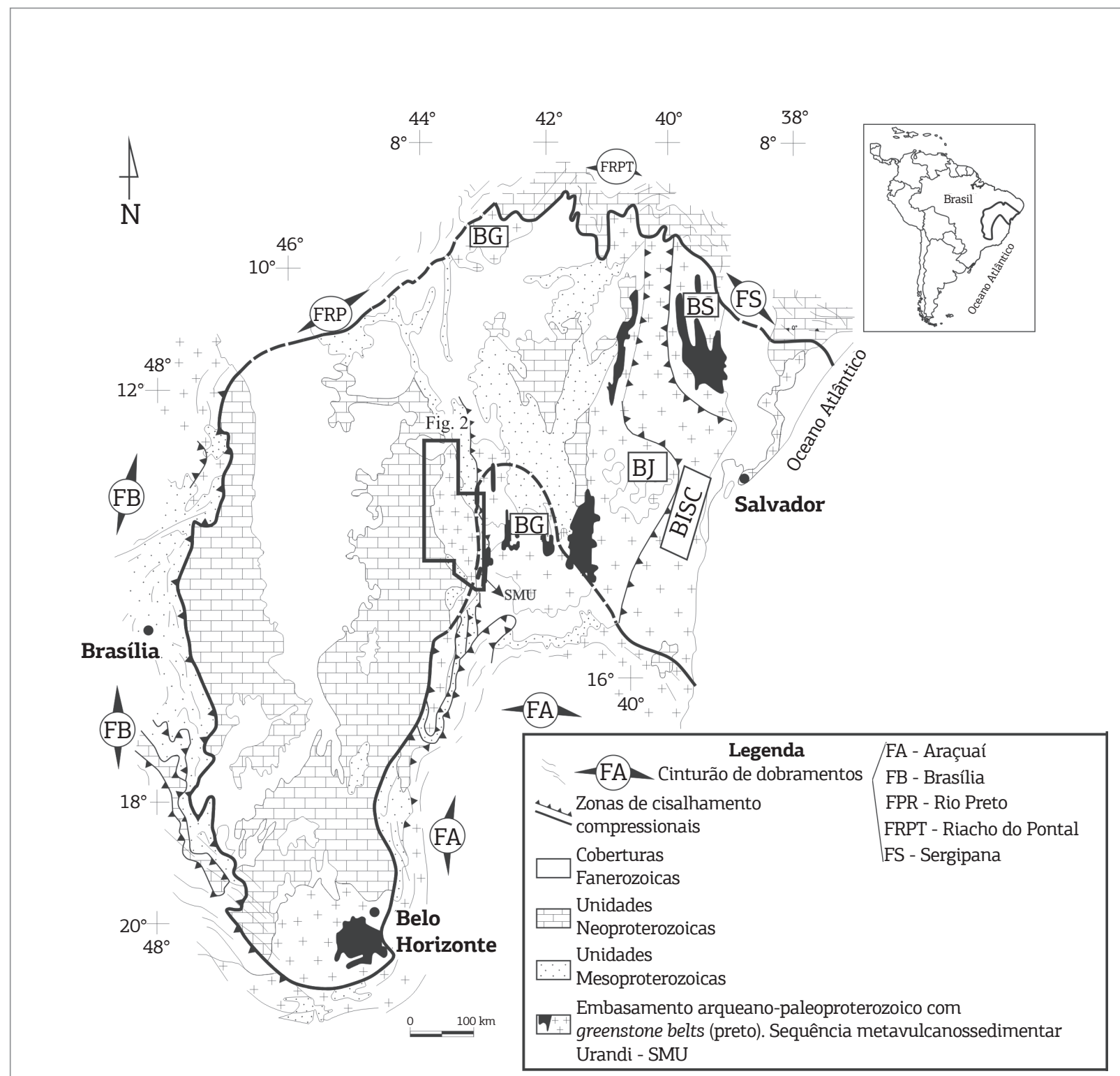

BG: Bloco Gavião; BJ: Bloco Jequié; BS: Bloco Serrinha; BISC: Bloco Itabuna-Salvador-Curaçá. Adaptado de Alkmim, Brito Neves \& Alves (1993). $\mathrm{O}$ retângulo indica a área da Figura 2.

Figura 1. Mapa geológico do Cráton do São Francisco com as principais unidades geológicas e as faixas marginais. 
SMU foi pouco estudada até o presente, podendo ser citados os trabalhos de Moraes et al. (1980) e Melo (1984).

No presente artigo, serão apresentados os resultados dos estudos petrográficos e estruturais realizados a partir do mapeamento geológico de detalhe (1:2.000). A partir dos dados apresentados, espera-se poder contribuir para o entendimento do contexto geológico das sequências metavulcanossedimentares do Bloco Gaviáo, fundamentar os modelos prospectivos na regiáo e colaborar com o estudo da evoluçáo tectônica da porção setentrional do Orógeno Araçuaí.

\section{CONTEXTO GEOLÓGICO REGIONAL}

A SMU está posicionada tectonicamente na porção setentrional do Orógeno Araçuaí e integra o contexto das unidades do Bloco Gavião. No âmbito regional, afloram as unidades do Complexo Santa Isabel (Barbosa e Moutinho da Costa 1973, Portela et al. 1976, Mascarenhas 1979, Moutinho da Costa \& Silva 1980, Fernandes et al. 1982), as rochas do Greenstone Belt Riacho de Santana (Moutinho da Costa \& Silva 1980) e do Batólito Monzosienítico Guanambi-Urandi (Rosa et al. 1996 e Rosa 1999), bem como unidades do Supergrupo Espinhaço e São Francisco (Fig. 2).

O Complexo Santa Isabel caracteriza-se como uma extensa faixa de metamorfitos com trend, em geral N-S, com 11 a $25 \mathrm{~km}$ de largura e $310 \mathrm{~km}$ de comprimento (Santos 1999). De acordo com Barbosa \& Moutinho da Costa (1973), Portela et al. (1976), Fernandes et al. (1982) e Arcanjo et al. (2005), nesse complexo afloram granulitos, rochas calcissilicáticas, anfibolitos, gabros/dioritos e noritos, metapiroxenitos, charnoquitos, tonalitos, charno-enderbitos e noritos. Essa sequência encontra-se intrudida por rochas graníticas. A presença de eclogitos foi citada por Barbosa e Moutinho da Costa (1973) na porção norte dessa unidade. A paragênese cordierita, microclina, ortopiroxênio encontrada nos gnaisses kinzigíticos sugere que essas rochas foram submetidas às condiçóes de fácies granulito (Arcanjo et al. 2005).

Os trabalhos geocronológicos existentes sobre este segmento crustal, Jardim de Sá et al. (1976) e Brito Neves, Cordani e Torquato (1980), obtiveram, pelo método $\mathrm{Rb} / \mathrm{Sr}$, isócrona a $2570 \pm 220 \mathrm{Ma}$ e $2680 \pm 83 \mathrm{Ma}$, respectivamente. Fernandes et al. (1982) e Mascarenhas e Garcia (1989), aplicando o mesmo método geocronológico, definiram as idades 2700 e $3030 \pm 107 \mathrm{Ma} / 2685 \pm 97 \mathrm{Ma}$, respectivamente. Recentemente, Barbosa (2010) obteve uma idade $\mathrm{Pb}-\mathrm{Pb}$ em torno de 3,4 Ga para esse complexo na região de Riacho de Santana.

O Greenstone Belt Riacho de Santana (Moutinho da Costa \& Silva 1980, Silveira, Fróes \& Bastos Leal 1996, Silveira \& Garrido 1998, Arcanjo et al. 2005) ocorre segundo uma faixa N-S com, aproximadamente, $84 \mathrm{~km}$ de comprimento e largura média de $12 \mathrm{~km}$. De acordo com esses autores, nesse greenstone distinguem-se três unidades:

a unidade inferior de xistos quartzosos com moscovita e, subordinadamente, biotita; xistos aluminosos com biotita, moscovita, clorita, quartzo, cordierita e silimanita; intercalaçốes de xistos granadíferos à espessartita; anfibolitos; formaçóes ferríferas bandadas e rochas ultramáficas com textura spinifex;

a unidade intermediária, que compreende rochas básicas toleíticas, xistos aluminosos, metacherts, grafita xistos e grafititos; e

- a unidade superior, composta por lentes de metacherts, quartzitos finos, mármores, formação ferrífera bandada e rochas calcissilicáticas.

O Batólito Monzo-sienítico de Guanambi-Urandi (Rosa et al. 1996, Rosa 1999) é intrusivo no Complexo Santa Isabel e recobre uma área com cerca de $6000 \mathrm{~km}^{2}$, sendo subdividido em dois componentes principais: domínio das intrusóes múltiplas e domínio das intrusôes tardias. O primeiro perfaz cerca $92 \%$ do batólito, sendo constituído por rochas sienítica, monzonítica e granítica, com termos monzo-dioríticos subordinados. Os plútons tardios são denominados de Cara Suja (Paim et al. 1998), Ceraíma (Leahy 1997), Estreito (Santos 1999), e compreendem rochas leucocráticas, porfiríticas a faneríticas médias, inequigranulares, que foram agrupadas em três fácies principais: quartzo-sienítica, monzogranítica e álcali-felspática-sienítica (Rosa 1999). Idades $\mathrm{U}-\mathrm{Pb}$ (método de diluição isotópica em zircão) foram obtidas para as intrusões múltiplas $(2054 \pm 8 \mathrm{Ma})$ e tardias $(2053 \pm 3 \mathrm{Ma}, 2050.4 \pm 1$ Ma e $2054 \pm 3 \mathrm{Ma}$, para os corpos Cara Suja, Ceraíma e Estreito, respectivamente) por Rosa et al. (1996) e Rosa (1999).

As unidades do Supergrupo Espinhaço, de idade Paleo-Mesoproterozoica, afloram na Serra do Espinhaço Setentrional e na Bacia do São Francisco. Na Serra do Espinhaço Setentrional afloram as rochas do Grupo Santo Onofre (Arcanjo et al. 2005, Loureiro et al. 2010, Guimarães, Alkmim \& Cruz 2012). Da base para o topo podem ser individualizadas as seguintes formaçóes:

- Fazendinha, que compreende metarenito feldspático e metaquartzoarenito com estratificaçôes planoparalelas, cruzadas tangenciais, acanaladas de grande porte a gigantes;

- Serra da Vereda, com metaconglomerados oligomíticos matriz-sustentados;

- Serra da Garapa, que compreende filitos e metapelitos hematíticos, grafitosos e/ou manganesíferos e sericíticos, interestratificados com metarenito feldspático e metaquartzarenito; (iv) Boqueirão, com 


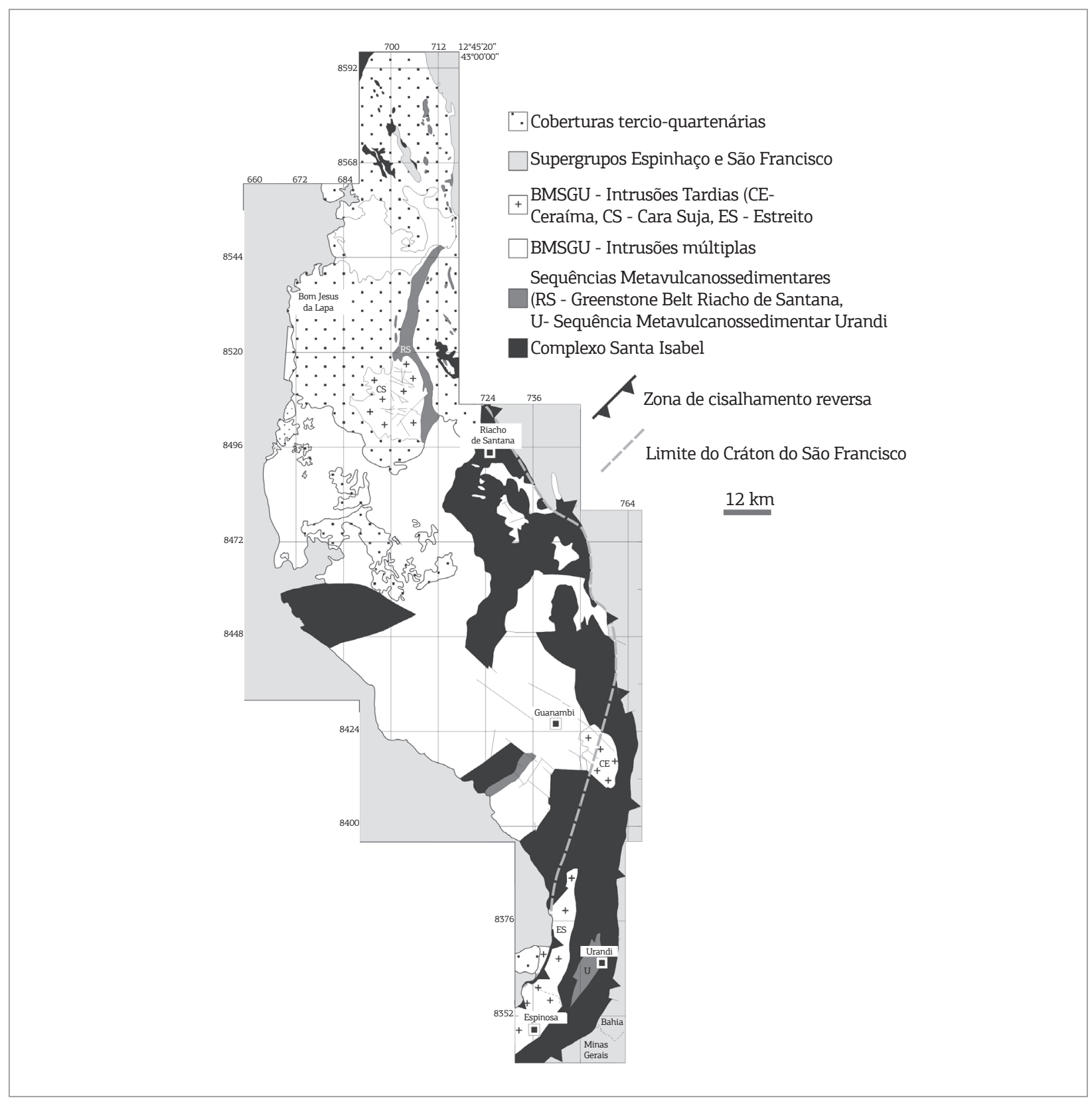

Figura 2. Mapa geológico mostrando o contexto regional da Sequência Metavulcanossedimentar Urandi. Modificado de Rosa (1999).

metaquartzoarenito, metarenito feldspático, metabrecha conglomerática polimítica, metaconglomerado polimítico, metarenito lítico, metarcóseo, metapelito carbonático e chert.

O Supergrupo São Francisco, de idade Neoproterozoica, aflora na bacia homônima. Nesse supergrupo podem ser reconhecidas duas unidades principais: o Grupo Macaúbas, que compreende sedimentos glácio-continentais (diamictitos, arenitos e pelitos) e o Grupo Bambuí, constituído por rochas carbonáticas que se intercalam com sedimentos terrígenos (Alkmim \& Martins-Neto 2001).

\section{A SEQUÊNCIA METAVULCASSEDIMENTAR URANDI}

A Sequência Metavulcanossedimentar Urandi SMU possui como rocha encaixante ortognaisses e migmatitos do Complexo Santa Isabel. De acordo com Medeiros et al. (2011) e Medeiros (2012), nesse complexo afloram rochas metatexíticas e diatexíticas, cuja migmatização, baseado em dados U-Pb (zircão, Laser Ablation e Shrimp), ocorreu com idade mínima de $2.095 \pm 8,6 \mathrm{Ma}$. O contato leste da SMU com as unidades do Complexo Santa Isabel ocorre através de zona de 


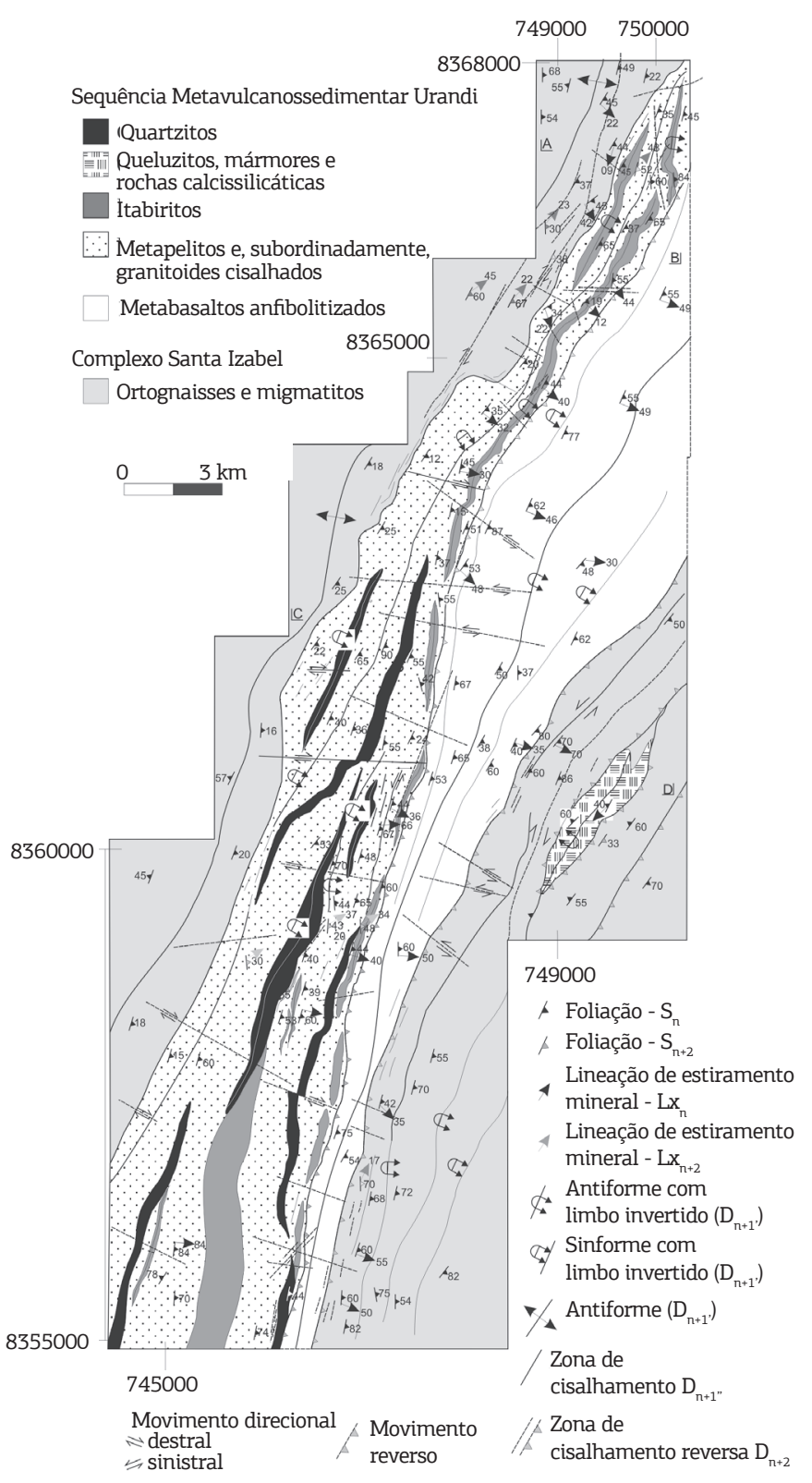

Figura 3. Mapa geológico da Sequência Metavulcanossedimentar Urandi. Modificado de Figueiredo (2009).

cisalhamento reversa com orientação NE-SW (Fig. 3). O contato oeste, por sua vez, é marcado por uma zona de cisalhamento de baixo ângulo, que possivelmente representaria o descolamento basal entre a SMU e o Complexo Santa Isabel.

Apesar da intensa deformação, a SMU pode ser subdividida em unidade basal, constituída por intercalaçóes de metabasaltos anfibolitizados, e na unidade superior com itabiritos, metapelitos, queluzitos, mármores, calcissilicáticas e quartzitos (Figs. 4 e 5). Essas rochas encontram-se fortemente deformadas e, em alguns casos, milonitizadas.
No contato entre elas hospedam-se de zonas de cisalhamento interestratais. Intrusivos nessa sequência ocorrem monzogranitos formando sills e diques (Fig. 6). Na maioria dos corpos observados a foliação é pouco desenvolvida, mas pode estar presente nas bordas dos sills.

\section{Petrografia}

\section{Metabasaltos anfibolitizados}

Os metabasaltos ocorrem na porção centro-oriental (Fig. 3) e recobrem cerca de $20 \%$ da área total cartografada. 

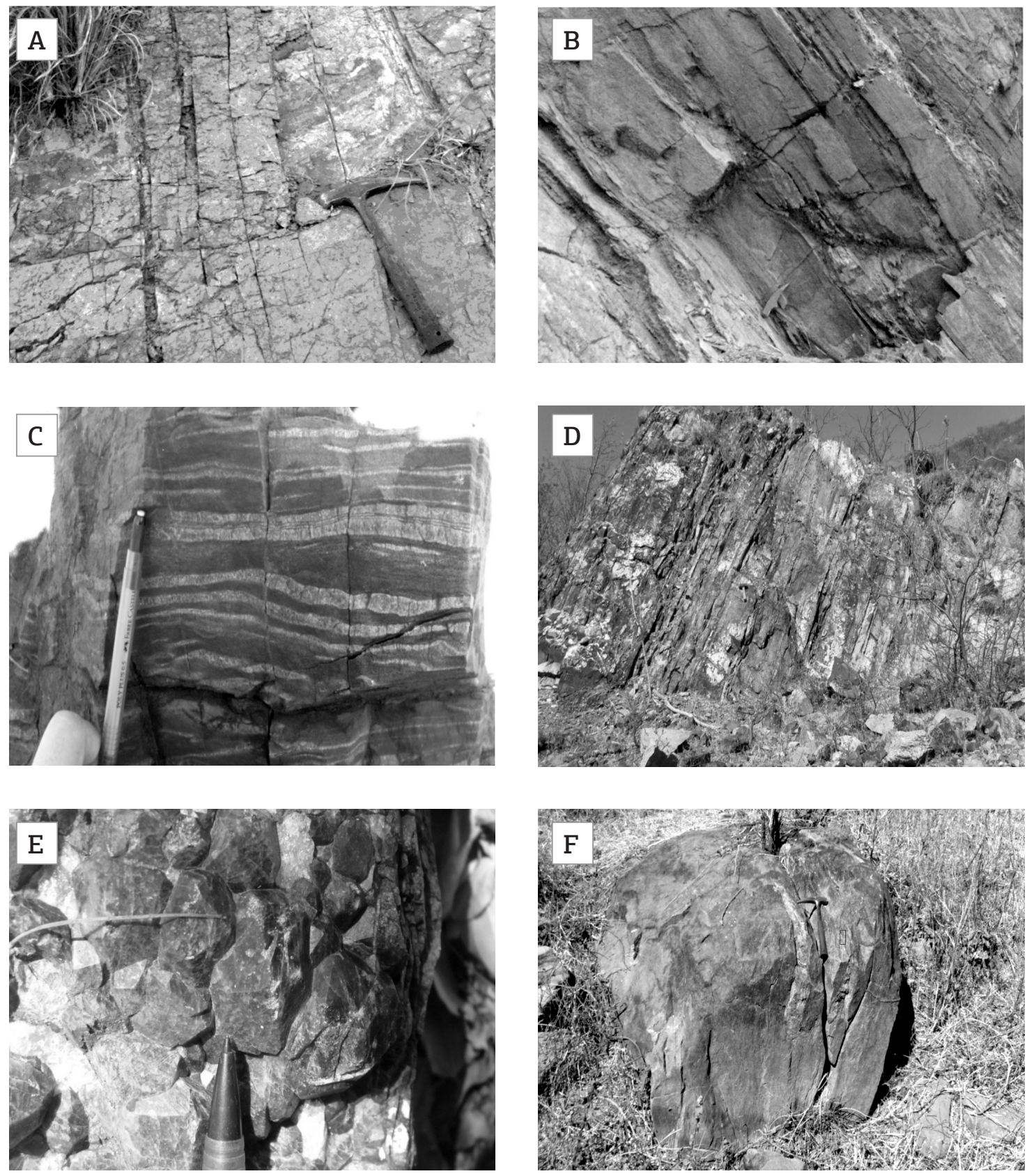

Figura 4. Vista panorâmica dos afloramentos de metabasaltos anfibolitizados (A), metapelitos (B), itabirito (C); mármores, calcissilicáticas e queluzitos (D); veio de granada e quartzo em calcissilicáticas e queluzitos (E) e quartzitos $(\mathrm{F})$.

Intercalaçóes dessas rochas com níveis finos de itabiritos são comumente observados. Como mencionado anteriormente, o contato leste dessa unidade com os gnaisses do Complexo Santa Isabel é marcado pela zona de cisalhamento reversa, assim como o contato a oeste com os metapelitos da Sequência Metavulcanossedimentar Urandi.

Essas rochas possuem coloração cinza-esverdeada, granulação fina a afanítica, e raros domínios com fenocristais de plagioclásio (Fig. 4A). Nos afloramentos, é comum a presença de uma foliação, penetrativa conferindo um caráter anisotrópico à unidade. As microestruturas metamórfico-deformacionais comumente descritas nessas rochas são (Figs. 5A e B):

nematoblástica, marcada pela orientação da hornblenda;

- granoblástica, assinalada pela presença de agregados poligonais de plagioclásio gerados por recristalização (Fig. 5B); 

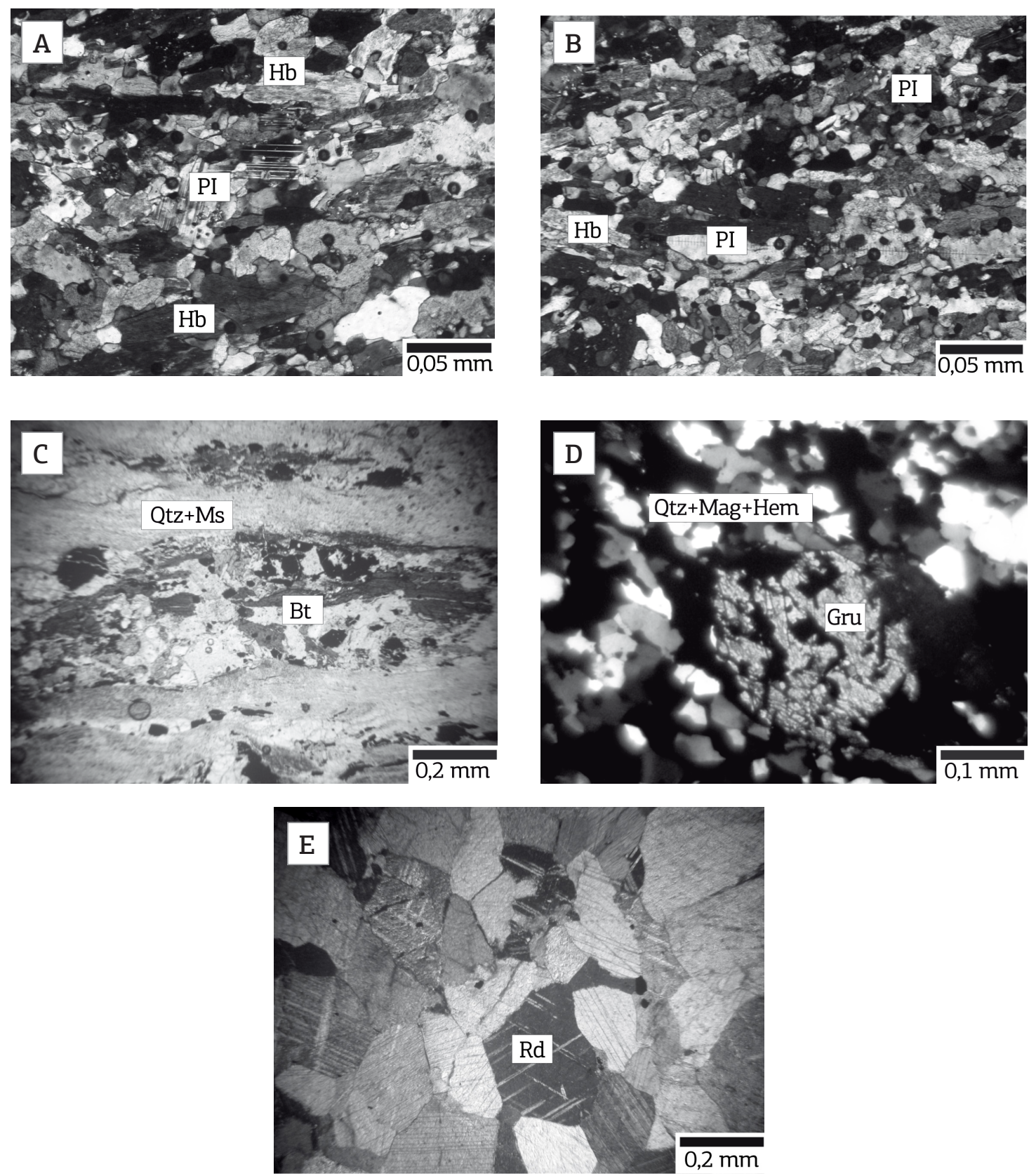

Pl: plagioclásio; Hem: hematita; Mag: magnetita.

Figura 5. Microfotos de hornblenda (Hb) (A) e (B) em metabasaltos anfibolitizados. Notar a presença de grãos poligonais de plagioclásio na foto b e de porfiroclastos nessas fotos; (C) metapelito com biotita (Bt), quartzo (Qtz) e moscovita (Ms); (D) grunerita (Gru) em itabirito e (E) rodocrosita (Rd) em queluzito.

pseudopoiquiloblástica, representada pelo crescimento de epidoto, calcita e moscovita em fraturas e clivagens do plagioclásio;

- milonítica, porfiroclástica e núcleo-manto, pela presença de agregados poligonais contornando porfiroclastos (antigos fenocristais de plagioclásio);
- reação, revelada pela transformação do diopsídio em hornblenda durante o metamorfismo progressivo, bem como pelo aspecto esqueletiforme de calcita, epidoto, biotita e moscovita substituindo a hornblenda nas bordas e nas clivagens desse anfibólio durante a alteração hidrotermal. 


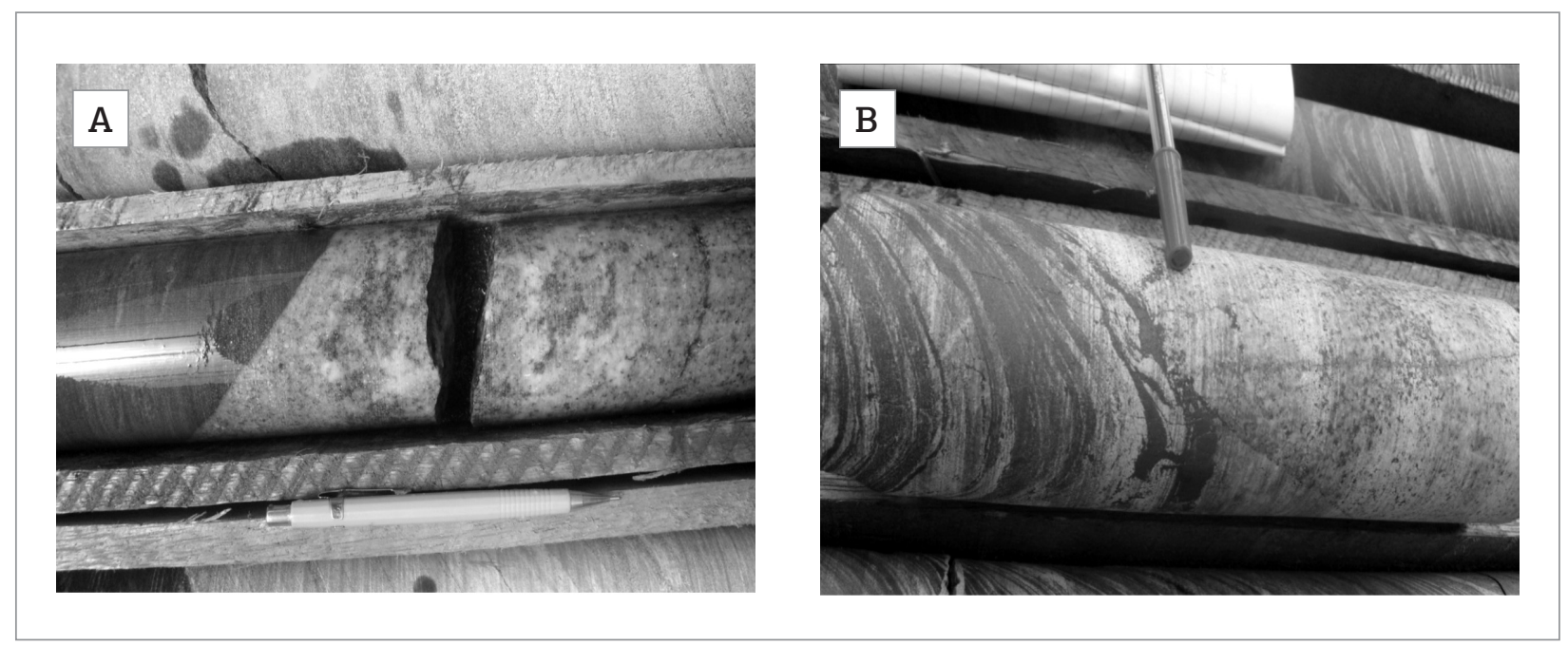

Figura 6. Monzogranitos intrusivos (A) discordantes e (B) concordantes com a foliação Sn em itabiritos. Notar em (B) o granitoide cisalhado no contato com o itabirito.

O diopsídio, com proporção modal variando entre 2-5\%, provavelmente é um mineral ígneo. A paragênese metamórfica progressiva de fácies anfibolito observada nessas rochas é constituída por hornblenda $(60-70 \%)$, plagioclásio $(27-32 \%)$, titanita $(1-3 \%)$ e magnetita/ilmenita $(1-4 \%)$. Como minerais de alteração hidrotermal são descritos: clorita $(0-5 \%), \mathrm{Fe}-$ biotita $(0-2 \%)$, epidoto $(0-2 \%)$, quartzo $(0-2 \%)$ e calcita $(0-1 \%)$. O diopsídio é incolor, forma grãos esqueletiformes ou prismas curtos, é xenoblástico ou subidioblástico, respectivamente, com tamanho variando entre 0,01 a 0,3 $\mathrm{mm}$. Em geral, encontram-se inclusos na hornblenda com bordas irregulares e possivelmente corroídas pelo crescimento do anfibólio. Essa relação sugere a atuação de reação metamórfica, como por exemplo: anfibólio+ 6 clinozoizita + quartzo $=10$ anortita+ 4diopsídio+ 4 $\mathrm{H}_{2} \mathrm{O}$ (Bucher \& Grapes 2011). A hornblenda (Figs. 5A e B) possui pleocroísmo variando entre verde oliva e verde-castanho, é prismática e ocorre subidioblástica, com granulometria entre 0,12 e 0,46 mm. No interior desse mineral há grãos esqueletiformes de calcita que crescem nas clivagens e fraturas do hospedeiro e inclusões de quartzo. Além disso, é substituída pela biotita e calcita ao longo das clivagens e em suas bordas.

O plagioclásio ocorre na matriz das rochas (Figs. 5A e B), formando agregados poligonais recristalizados. As raras geminaçôes preservadas são polissintéticas, do tipo albita. Esse é um mineral ígneo que foi re-equilibrado durante o metamorfismo. Encontra-se parcialmente substituído por calcita, moscovita e epidoto em clivagens e fraturas. A titanita é castanha, prismática e ocorre em tamanhos inferiores a $0,1 \mathrm{~mm}$. A magnetita e a ilmenita são anédricas e apresentam-se orientadas segundo a foliação principal, com tamanhos variando entre 0,08 e 0,1 mm. Em geral, associam-se com a titanita.

A clorita é verde pálida, com cor de interferência cinza de primeira ordem, são biaxiais positivas e possuem elongação negativa, sugerindo a presença de $\mathrm{Mg}$ Clorita. Microdobra do tipo kink-band está associada à esse mineral. A biotita possui pleocroísmo variando entre castanho e verde-castanho, é lamelar, subidioblástica e ocorre esqueletiforme nas fraturas da hornblenda ou nas bordas desse mineral. O epidoto possui cor verde pálida e apresenta-se com habito maciço associado ao plagioclásio, com tamanho variando entre $0,1 \mathrm{e}$ $0,3 \mathrm{~mm}$. A calcita apresentam-se esqueletiformes e desenvolve-se em fraturas e clivagens do anfibólio e do plagioclásio, com tamanho inferior a $0,2 \mathrm{~mm}$.

\section{Metapelitos}

Estas rochas são observadas ao longo de toda área (Figs. 4B e 5C) e estão intercaladas com metabasaltos anfibolitizados, itabiritos e quartzitos, ocupando cerca de $20 \%$ da área total cartografada. O levantamento geológico realizado permitiu identificar e individualizar, na escala de mapa, um conjunto indiferenciado composto por biotita xisto, quartzo-biotita xisto, quartzomuscovita-clorita-biotita xisto, biotita-moscovita xisto, almandina-biotita xisto e quartzo-moscovita xisto. Essas rochas são anisotrópicas, com microestruturas metamórfico-deformacionais:

- lepidoblástica, pela orientação preferencial de biotita e moscovita; 
granoblástica interlobada, pelos agregados granulares de quartzo com bordas reentrantes;

- porfiroclástica, miloníticas e núcleo-manto, pelos agregados poligonais de quartzo contornando porfiroclastos desse mineral;

- porfiroblástica e helicítica, pelo crescimento intercinemático da almadina e pela presença de foliação interna dobrada e marcada pela orientação preferencial das inclusôes de quartzo;

- poiquiloblástica exibida pelas inclusóes de quartzo, biotita e moscovita em almandina.

A proporção modal calculada nas amostras analisadas é quartzo (37 - 44\%), moscovita $(33$ - 39\%), biotita $(7-12 \%)$, almandina $(0-15 \%)$, magnetita $(0-10 \%)$ e clorita $(0-12 \%)$. O quartzo apresenta-se xenoblástico, como porfiroclastos ou como agregados de grãos poligonais. Os grãos poligonais medem entre 0.2 e $0,45 \mathrm{~mm}$, ao passo que os porfiroclastos podem atingir $2 \mathrm{~mm}$. A extinção é fortemente ondulante e, também, nesse caso, a presença de novos grãos poligonais com tamanhos e geometria próximas a subgrãos, sugerem mecanismos de recristalização por rotação de subgrãos. A muscovita e a biotita são subidioblásticas, ocorrem orientadas segundo a foliação da rocha e apresentam extinção ondulante, além de microdobra do tipo kink band. O tamanho varia entre 0,5 e $1,5 \mathrm{~mm}$. A almandina apresenta-se subidioblástica e idioblástica, com tamanhos variando entre 0,6 a $1.6 \mathrm{~mm}$. Em geral, a foliação externa contorna os porfiroblastos, enquanto a foliação interna encontra-se reorientada, mas em continuidade com a foliação externa, sugerindo um crescimento sintectônico à foliação $\mathrm{Sn}$. A clorita ocorre nas bordas e nas clivagens da granada. A magnetita forma porfiroblastos idioblásticos pós-tectonicos à foliação da rocha, com tamanhos que podem atingir 1,2 $\mathrm{mm}$.

\section{Itabiritos}

Essas rochas ocorrem especialmente no domínio centro-ocidental da área de pesquisa (Fig. 3), expostas geomorfologicamente pelas maiores altitudes locais. Em geral, são representados por itabiritos micro a macrobandados/laminados, predominando os termos mesobandados (Trendall 2002, Trendall \& Blockley 2004). Essas rochas formam níveis contínuos intercalados com metapelitos e com metabasaltos anfibolitizados.

Mineralogicamente, essas rochas possuem uma característica monótona, apresentando como minerais principais, hematita $(0-15 \%)$, martita $(0-12 \%)$, magnetita $(25-77 \%)$, quartzo $(20-68 \%)$, grunerita $(0-7 \%)$ (Fig. 5D) e Fe-clorita $(0-5 \%)$ com porçôes de alteração supergênica que propiciaram a formação de goethita e limonita. O quartzo ocorre xenoblástico, formando grãos alongados e/ou poligonais, com forte extinção ondulante. A hematita e a magnetita são predominantemente anédricas e granulares. A hematita pode ocorrer alongada, neste caso, posicionando-se concordantemente com a foliação da rocha. A Fe-clorita ocorre nas clivagens e bordas da grunerita.

\section{Queluzitos, mármores e rochas calcissilicáticas}

Essa unidade encontra-se no setor leste (Fig. 3), recobrindo uma área com cerca $1,12 \mathrm{~km}^{2}$. A ocorrência de abundantes afloramentos foram propiciados pela antiga exploração de minério de manganês da Mineração Urandi Ltda, na denominada Mina Barreiro dos Campos (Fig. 4D), onde atualmente, não há atividade exploratória. Os minerais de minério são a criptomelana e outros oxi-hidróxidos de $\mathrm{Mn}$ associados a um protominério queluzítico. A rodrocrosita encontra-se recristalizada, dando origem à microstrutura granoblástica poligonal (Fig. 5E). Associados aos queluzitos podem ser encontrados mármores manganesíferos e tremolita-diopsídio-rodocrosita mármore. De forma subordinada foi identificada a presença de tremolita-espessartita xisto, calcita-tremolita-espessartita xisto e rochas calcissilicáticas (Borges 2008). Veios de quartzo, magnetita e almandina truncam a foliação das rochas dessa unidade (Fig. 4E).

\section{Quartzitos}

Essas rochas (Fig. 4F) afloram na região central da área cartografada (Fig. 3), recobrindo cerca de 7\% do seu total. $\mathrm{Na}$ porção centro-leste da área cartografada, os quartzitos ocorrem intercalados com metapelitos.

Apresentam coloração bege a bege-esbranquiçada, quando puros ou com minerais micáceos, e bege-avermelhada, quando ferruginosos, com granulação variando entre $0,2 \mathrm{e}$ $1 \mathrm{~mm}$. Os quartzitos apresentam uma foliação marcada pela orientação preferencial de grãos estirados de quartzo e, em menor proporção, quando presentes, pela orientação de biotita e moscovita. Predominantemente são constituídos por quartzo, sendo que ocorrem biotita, moscovita e hematita em proporçóes menores que $5 \%$ do total da rocha. Nos quartzitos ferruginosos a proporçáo de hematita pode atingir $12 \%$ do total da rocha. Minerais como goethita e limonita ocorrem em menor proporção. Em função da variação modal, durante os levantamentos foram individualizados em quartzitos puros e micáceos, quartzitos ferruginosos, neste caso enriquecidos em hematita e magnetita, ambas dispersas na matriz, além de biotita-moscovita quartzito.

As microestruturas encontradas foram:

- porfiroclástica, núcleo-manto e milonítica, que nesse caso está relacionada com a presença de grãos recristalizados nas bordas de profiroclastos de quartzo 
lepidoblástica, pela orientação preferencial da biotita e moscovita segundo a foliação da rocha nos dominios de maior concentração desses filossilicatos. Nessas rochas o quartzo apresenta-se granoblástico interlobado e também alongado segundo a foliação preferencial, com tamanho variando entre 0,5 e $2 \mathrm{~mm}$. Os novos grãos poligonais possuem tamanhos e geometrias próximas a de subgrãos, sugerindo mecanismos de recristalização por rotação de subgráos. Como mencionado anteriormente, os minerais micáceos podem ser encontrados imersos na matriz das rochas. A biotita possui pleocroísmo variando entre verde claro e verde oliva, é lamelar, e, assim como a micabranca, pode ser observada em amostra de mão com tamanho de até $1 \mathrm{~mm}$. A hematita e magnetita ocorrem em grãos anédricos, podendo apresentar orientação preferencial.

\section{Arcabouço estrutural}

\section{Fases deformacionais}

O levantamento estrutural permitiu a identificar três fases de deformação, descritas como, $\mathrm{D}_{\mathrm{n}}, \mathrm{D}_{\mathrm{n}+1}$ e $\mathrm{D}_{\mathrm{n}+2}$, que se desenvolvem na Sequência Metavulcanossedimentar de Urandi e no Complexo Santa Isabel. A fase $\mathrm{D}_{\mathrm{n}+1}$ é subdividida em dois estágios deformacionais progressivos, denominadas de $\mathrm{D}_{\mathrm{n}+1}$, e $\mathrm{D}_{\mathrm{n}+1}$. Em conjunto, a distribuição e padrão cinemático encontrado na fase $\mathrm{D}_{\mathrm{n}}$ sugere um transporte de massa com vergencia para sudeste revelado pela presença de estruturas sigmoidais. Para as fases $\mathrm{D}_{\mathrm{n}+1}$ e $\mathrm{D}_{\mathrm{n}+2}$, por sua vez, o encurtamento geral é segundo WNW-ESSE a NW-SE e WSW-ENE, respectivamente. As fases $\mathrm{D}_{\mathrm{n}}$ e $\mathrm{D}_{\mathrm{n}+1}$ estão equilibradas no fácies anfibolito médio, ao passo que a associação mineralógica associada com a fase $\mathrm{D}_{\mathrm{n}+2}$ é de fácies xisto verde.

As estruturas associadas à fase deformacional Dn são predominantemente dúcteis, tendo sido responsáveis pela formação de uma xistosidade $S_{n}$ e pela geração de dobras intrafoliais, isoclinais, sem raiz (Figs. 7A e B). Essa foliação ocorre paralelizada com estruturas mais antigas $\left(\mathrm{S}_{\mathrm{n}-1}\right.$ ?, $\mathrm{S}_{0}$ ?). Nos itabiritos a foliação $S_{n}$ é definida pela orientação preferencial da especularita, nos metabasaltos ela é preferencialmente marcada pela orientação do anfibólio, nos quartzitos pelo estiramento do quartzo e nos metapelitos pela orientação de biotita e moscovita, bem como pelo estiramento do quartzo. Além disso, dobras em bainha, boudins, sigmoides de foliação e lineação de estiramento mineral $\left(\mathrm{L}_{\mathrm{xn}}\right)$ também foram nucleadas nesta fase. A foliação Sn possivelmente foi gerada por uma deformação não-coaxial, com nucleação de descolamentos intraestratais que se instalaram em todas as unidades da SMU, bem como entre essa sequência e o Complexo Santa Isabel. Esses descolamentos encontram-se muito bem preservados no limite oeste entre a SMU e esse complexo. Por outro lado, o limite leste da SMU o descolamento foi retrabalhado por cisalhamentos da fase $\mathrm{D}_{\mathrm{n}+2}$, descritos adiante.

Um bandamento composicional está associado a $\mathrm{S}_{\mathrm{n}} / /$ $\mathrm{S}_{\mathrm{n}-1}$ e está marcado: (i) pela alternância de níveis ricos em hematita/magnetita e níveis ricos em quartzo nos itabiritos; e (ii) por proporçóes variáveis entre quartzo, granada e filossilicatos nos metapelitos. A lineação de estiramento $\left(\mathrm{L}_{\mathrm{xn}}\right)$, por sua vez, ocorre marcada pelo quartzo e pelo anfibólio nas formaçôes ferríferas, pelo quartzo e minerais micáceos nos xistos e pelo anfibólio nas metavulcânicas.

A Fig. 8 apresenta os diagramas estereográficos sinópticos das estruturas da fase $\mathrm{D}_{\mathrm{n}}$. A distribuição da foliação Sn é assimétrica e a sua orientação geral apresenta um trend NE/SW. O plano preferencial posiciona-se em 108/46 (Fig. 8A). A lineação de estiramento mineral, por sua vez, posiciona-se com máximo em 105/63 (Fig. 8B).

A fase $D_{n+1}$ foi subdividida nas etapas $D_{n+1}$ e $D_{n+1}$. Associado com a etapa $\mathrm{D}_{\mathrm{n}+1}$, tem-se dobras com três graus de hierarquias distintas. A dobra de primeira ordem é uma megassinforme simétrica que estrutura as unidades da SMU e do Complexo Santa Isabel (Figs. 3 e 9). A SMU encontra-se estruturada segundo uma sinforme inclinada (Fleuty 1964), assimétrica, revirada (Twiss \& Moore 2007) e vergente para NW,, de segundo grau de hierarquia, que se posiciona no flanco oeste da estrutura de primeira ordem. Dobras parasíticas de terceiro grau de hierarquia e em S, M ou W e Z hospedam-se na megassinforme assimétrica que estrutura a SMU (Fig. 7C). As dobras desta fase desenvolvem-se rotacionando a foliação $S_{n}$, o bandamento associado e a lineação de estiramento mineral $\mathrm{L}_{\mathrm{xn}}$, anteriormente descritos. A foliaçáo plano axial sin- $\mathrm{D}_{\mathrm{n}+1}$, raramente é desenvolvida nessas estruturas. A Fig. 9 apresenta duas seçôes esquemáticas com a geometria estrutural geral da SMU e sua relação com o Complexo Santa Isabel.

Nos diagramas estereográficos das Figs. 8A e B, em que estão representados os dados para a a $S_{n}$ e $L_{x n}$, respectivamente, pode-se interpretar a distribuição dessas estruturas como relacionadas com as dobras da fase $\mathrm{D}_{\mathrm{n}+1}$, observada em campo (Fig. 7C). Na Fig. 8C, está representado o diagrama estereográfico das linhas de charneiras medidas em campo, tendo sido encontrados dois máximos preferenciais, posicionados em $020^{\circ} / 06^{\circ}$ e $176^{\circ} / 35^{\circ}$. Essa distribuição sugere que as dobras são acilíndricas com charneira curva e caimento principal para sul. A distribuição encontrada é compatível com a charneira calculada nas Figs. 8A e B.

A etapa de deformação $\mathrm{D}_{\mathrm{n}+1}$ " está representada por zonas de cisalhamento compressionais oblíquas, sinistrais a sinistral-reversas, dúcteis, com orientação NE-SW que truncam a foliação $\mathrm{Sn}$. Um sistema dúctil- rúptil a 

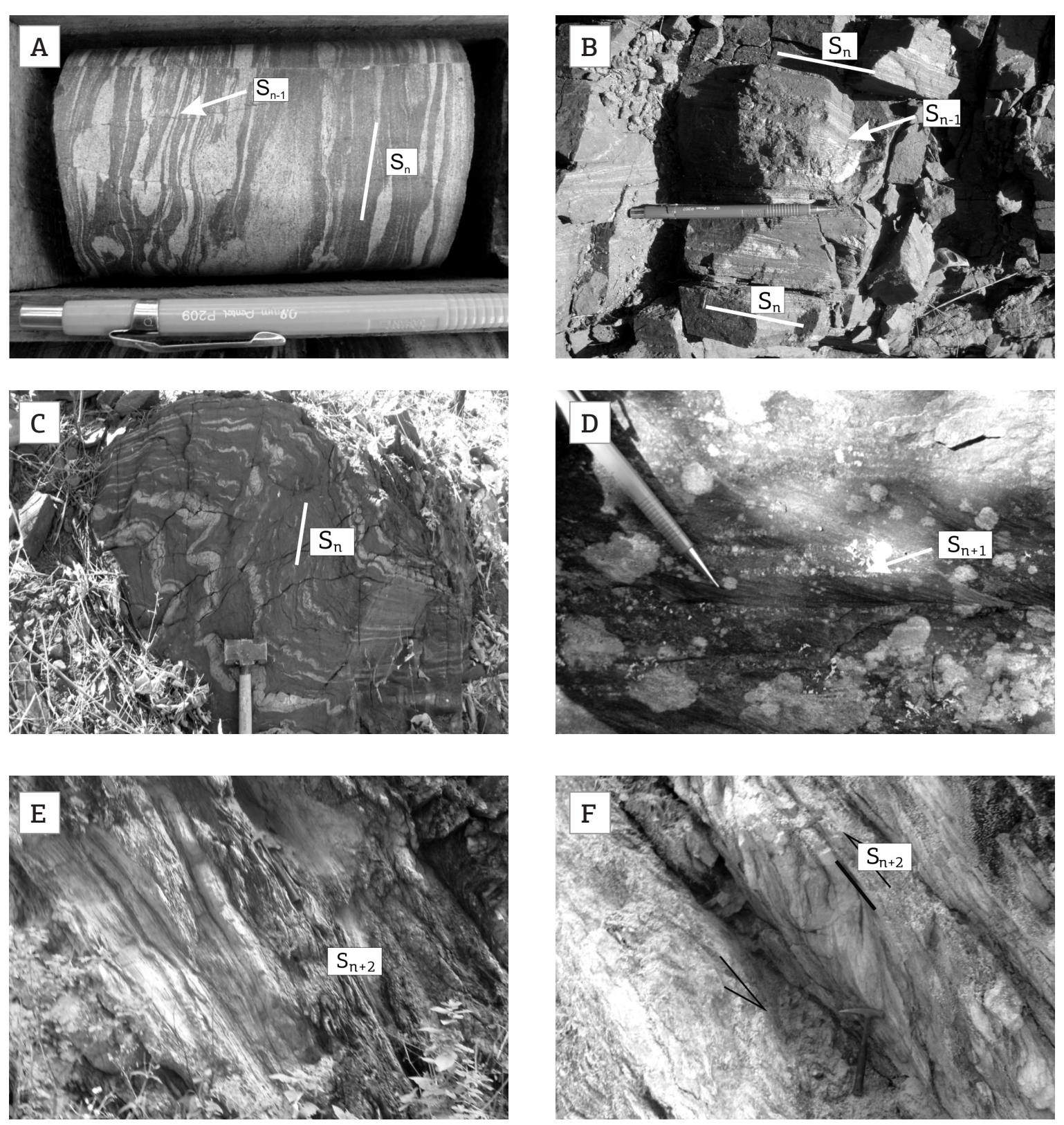

Figura 7. (A) Dobras isoclinais intrafoliais $\operatorname{Sin}-\mathrm{D}_{n}$ em itabiritos; (B) Boudins Sin- $D_{n}$; (C) Dobras Sin- $D_{n+1}$ em itabiritos; (D) zona de cisalhamento sinistral reversa nucleada em itabirito com orientação NNE-SSW (Estágio $D_{n+1}$, fase $\left.D_{n+1}\right)$; $(E)$ zona de cisalhamento reversa da fase $D_{n+2} ;(F)$ indicador cinemático (Estrutura $S / C$ ) em zona de cisalhamento reversa da fase $\mathrm{D}_{\mathrm{n}+2}$ (Detalhe da foto anterior).

rúptil-dúctil E-W com movimento aparente destral também está relacionado com essa etapa de deformação. Nas zonas de cisalhamento sinistrais $\mathrm{D}_{\mathrm{n}+1}$, é gerada uma foliação milonítica $S_{n+1}$ ", que posiciona-se preferencialmente segundo $091^{\circ} / 45^{\circ}$ (Fig. 8D). Pode-se verificar que nesse diagrama há uma maior dispersão dos dados, que é um reflexo da distribuição anastomótica das zonas de cisalhamento desta fase de deformação. A lineação de estiramento mineral $\left(\mathrm{L}_{\mathrm{xn}+1}\right)$ que está associada com as zonas de cisalhamento sinistrais da fase $\mathrm{D}_{\mathrm{n}+1}$, , por sua vez, está preferencialmente orientada segundo $008^{\circ} / 06^{\circ}$ e $182^{\circ} / 07^{\circ}$ (Fig. $8 \mathrm{E}$ ).

As zonas de cisalhamento sin- $\mathrm{D}_{\mathrm{n}+1^{\prime}}$ possuem ângulos predominantemente moderados a elevados, com forte componente de cisalhamento horizontal, ou seja, com lineaçóes de estiramento de média a baixa obliquidade. A cinemática sinistral e reversa recuperada em afloramentos das zonas de cisalhamento preferencialmente orientadas segundo NNE-SSW é marcada pela presença de dobras de arrasto e por sigmoides da foliação. 


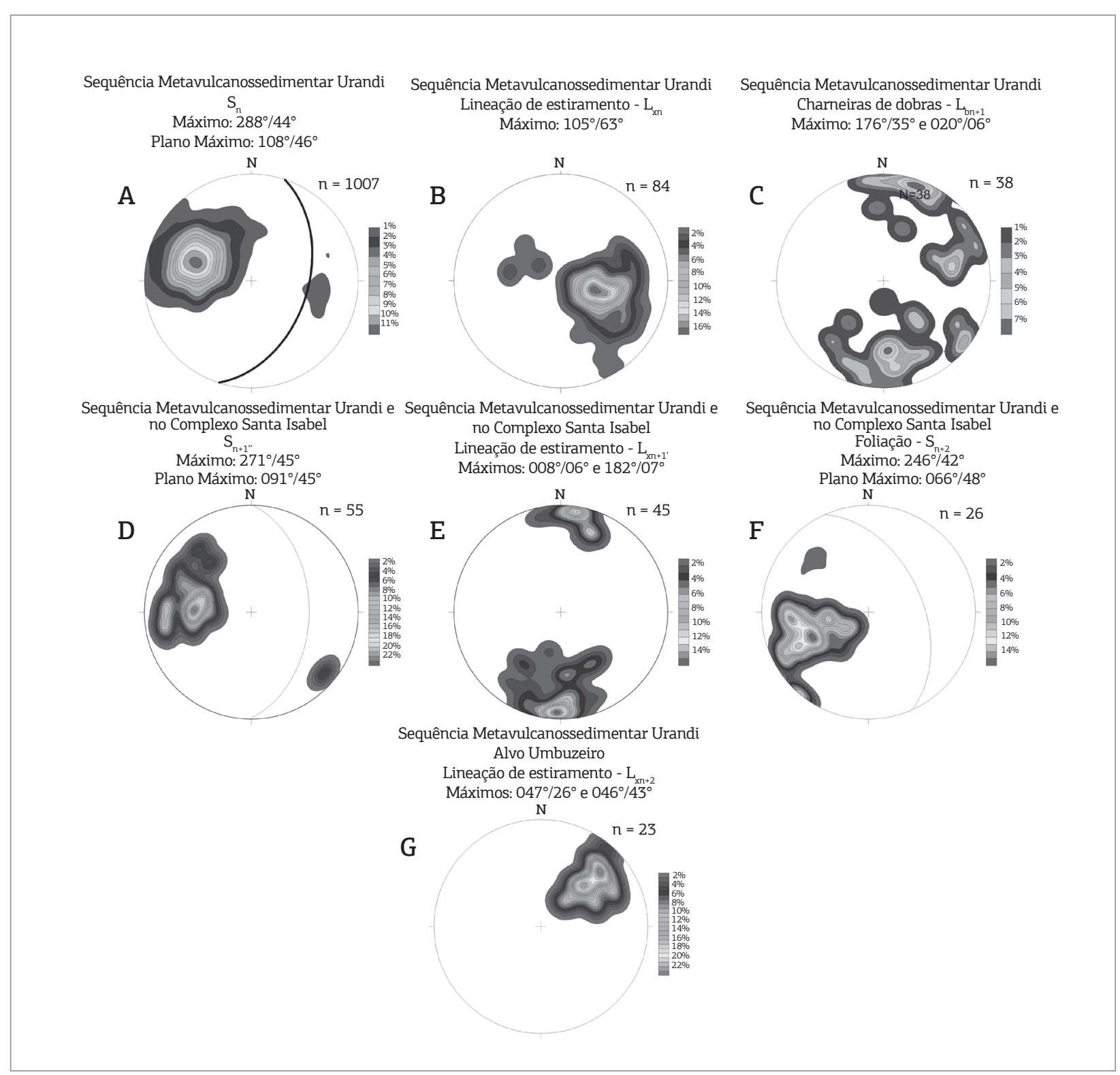

Figura 8. Diagramas estereográficos sinópticos de: (A) foliação $S_{n}$, (B) lineação de estiramento mineral (Lx $\left.x_{n}\right)$, (C) charneira de dobras $\mathrm{Lb}_{n+1}$, (D) foliaçao $S_{n+1}$, (E) lineação $L x_{n+1}$, (F) foliação $S_{n+2},(G)$ lineação Lx $x_{n+2}$. Nas figuras (A), (B), (D) e (F), em preto, estão representados os planos máximos. Hemisfério inferior.

$\mathrm{Na}$ fase $\mathrm{D}_{\mathrm{n}+2}$ foram geradas zonas de cisalhamento reversas a reversa-destrais, dúctil-rúpteis, com orientação preferencialmente segundo $066 / 48$. Os principais indicadores de movimento são as estruturas S/C (Figs. 7E e F). Além disso, associado com essa fase foi nucleada uma estrutura em flor positiva (Fig. 3) que estrutura o contato entre as rochas do Complexo Santa Isabel e os queluzitos, mármores e rochas calcissilicáticas da Sequência Metavulcanossedimentar Urandi (Fig. 9B) e que ancorase em uma zona de cisalhamento com orientaçáo NE-SW com cinemática destral. Nos ramos NW e SE dessa estrutura em flor podem ser encontrados leques imbricados, rampas de empurrão e duplexes com vergencia para NW e
SE, respectivamente. Além disso, dobras abertas com linha de charneira, em geral, de alto ângulo de caimento e orientada segundo NW-SE também compóem o arcabouço dessa fase deformacional e foram responsáveis pelo redobramento das estruturas da fase $\mathrm{D}_{\mathrm{n}+1}$. Essas estruturas truncam aquelas anteriormente desenvolvidas e possivelmente, em alguns casos podem se caracterizar como reativaçóes tectônicas das zonas de cisalhamento anteriormente nucleadas.

Em algumas das zonas de cisalhamento uma foliação milonítica pode ser observada, com intensa diminuiçăo da granulometria da rocha, configurando mesomilonitos (Fettes \& Desmons 2007) e ultramilonitos. A Fig. 8F apresenta a distribuição da foliação $S_{n+2}$, cuja orientaçâao preferencial é $066^{\circ} / 48^{\circ}$. 
A

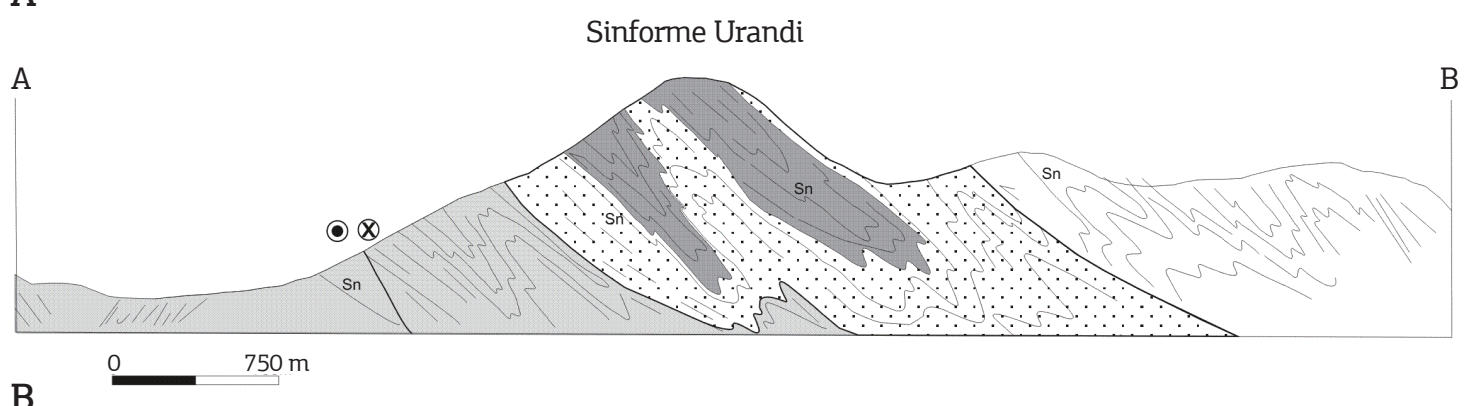

C

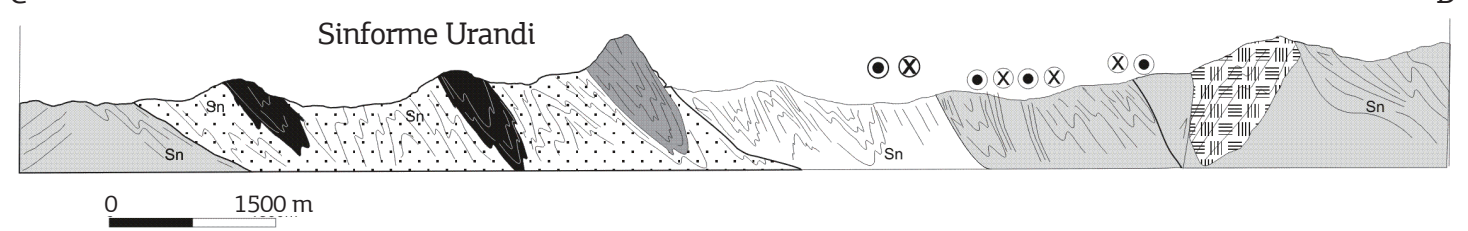

Sequência Metavulcanossedimentar Urandi
Quartzitos
Itabiritos

Movimento direcional $<$ Movimento reverso
Metapelitos e, subordinadamente, granitoides cisalhados

$\square$ Metabasaltos anfibolitizados

Complexo Santa Izabel

Ortognaisses e migmatitos

$\odot \otimes$ sinistral $\otimes \bullet$ destral

Figura 9. Perfis geológicos esquemáticos. A posição dos perfis está indicada na Figura 3. Escala horizontal igual à escala vertical.

Por sua vez, a lineação de estiramento mineral $\mathrm{L}_{\mathrm{xn}+2}$ situa-se com máximo em $047^{\circ} / 43^{\circ}$, sendo, portanto, de obliquidade elevada. Indicadores cinemáticos, tais como dobras de arrasto e estruturas S/C observadas no plano XZ conferem um caráter compressional a essas estruturas (Fig. 7F). Em alguns afloramentos é possível verificar uma lineação de média obliquidade em zonas de cisalhamento NW-SE, cuja posição em relação ao plano de cisalhamento sugere movimento com componente destral. Falhas com orientação WNW-ESE/WNW-ESE com movimento sinistral a sinistral reverso integram o arcabouço estrutural dessa fase de deformação. A paragênese mineral associada com essas zonas de cisalhamento é constituída por quartzo, $\mathrm{Mg}$ clorita e epidoto nos metabasaltos anfibolitizados da SMU. No Complexo Santa Isabel é constituída por moscovita e quartzo.

\section{Evolução deformacional}

A distribuição das estruturas deformacionais, assim com as relaçóes de truncamento entre elas permitiu elaborar um modelo de evolução deformacional apresentado na Fig. 10. A relação dessas estruturas com a mineralogia encontrada no estudo petrográfico encontra-se aprsentado na Fig. 11. Na primeira fase deformacional identificada, $D_{n}$, desenvolveu-se uma foliação $S_{n}$, cujo contexto deformacional ainda não foi elucidado. Nessa fase houve a transposição de uma estrutura anteriormente desenvolvida, que poderia ser uma foliação deformacional $\left(\mathrm{S}_{\mathrm{n}-1}\right)$ ou $\mathrm{S}_{0}$. Na fase seguinte, e no estágio inicial $\mathrm{D}_{\mathrm{n}+1}$, sinformes e antiformes assimétricos e, em geral, vergentes para NW foram gerados. Essa fase foi a responsável pela estruturação da megassinforme assimétrica Urandi que estrutura a SMU, bem como o Complexo Santa Isabel. Integrando os resultados desse trabalho com os dados obtidos por Medeiros et al. (2011) e Medeiros (2012) pode-se concluir que essa megassinforme representa uma dobra de segunda ordem que é parasítica de dobras regionais com envoltória simétrica. Essas estruturas foram truncadas por zonas de cisalhamento sinistral a 


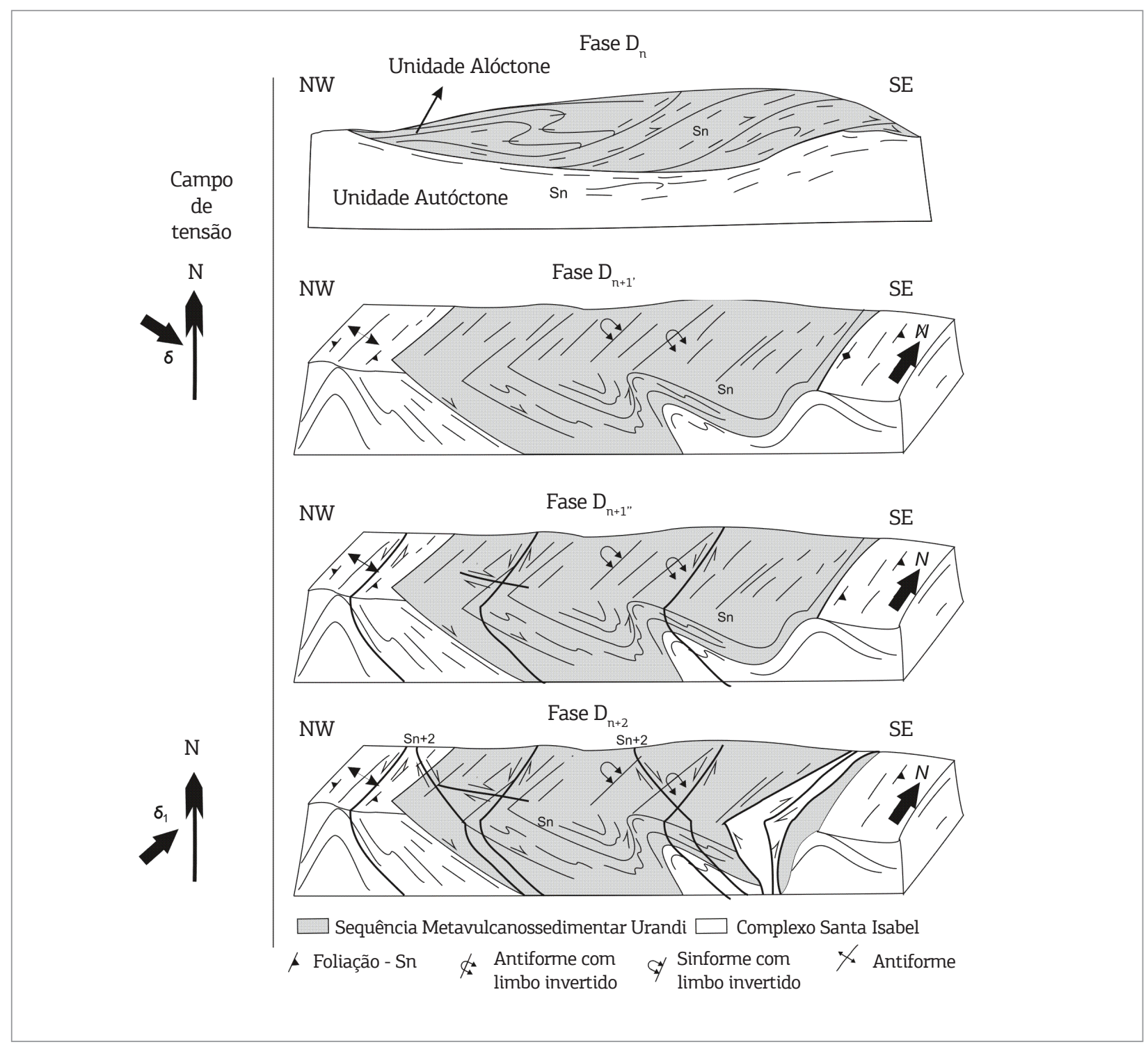

Figura 10. Evolução deformacional esquemática para a Sequência Metavulcanossedimentar Urandi.

reversa sinistral com orientação NE-SW e por zonas de cisalhamento destrais com orientação geral E-W. Essas estruturas já haviam sido descritas por Bertholdo (1993), embora o campo de tensão sugerido pelo autor tenha sido E-W.

Por fim, durante a fase $\mathrm{D}_{\mathrm{n}+2}$ rampas de empurrão, duplexes, estrutura em flor positiva e falhas reversas com orientação aproximadamente NS foram nucleadas. Associada a essa fase, zonas de cisalhamento sinistrais com orientação geral E-W são geradas, bem como dobras abertas com orientação geral NW-SE. No lado esquerdo da Fig. 10 pode ser observada a síntese dos campos de tensóes das sucessivas fases deformacionais identificadas.

A distribuição da foliação e da lineação de estiramento mineral, associada com as assimetrias encontradas em todas as escalas de deformação, permite inferir a direção geral de encurtamento para as fases identificadas. A fase $\mathrm{D}_{\mathrm{n}+1}$ possui campo de encurtamento segundo NW-SE. Por outro lado, durante $\mathrm{D}_{\mathrm{n}+2}$ o campo de tensão posiciona-se segundo WSW-ENE. Neste sentido, essa fase é não coaxial com relação às demais. As zonas de cisalhamento sinistrais posicionadas segundo E-W são compatíveis com esse campo de tensão.

\section{DISCUSSÃO DOS RESULTADOS}

Da base para o topo foram individualizados metavulcânicas máficas anfibolitizadas que são sobrepostas por um pacote constituído por formaçôes ferríferas bandadas, 


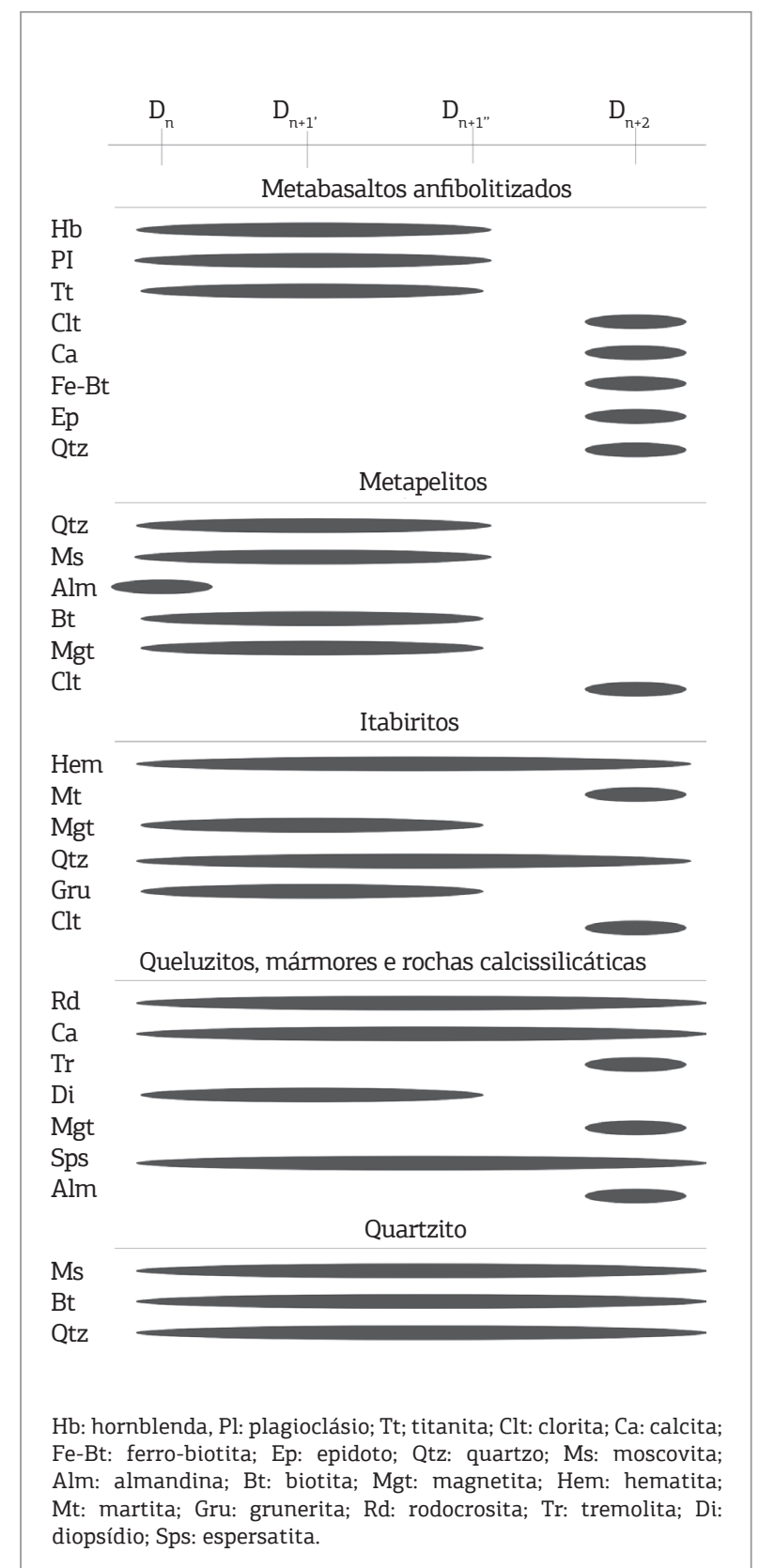

Figura 11. Quadro sinóptico de crescimento mineral versus deformação para a Sequência Metavulcanossedimentar Urandi.

metapelitos, rochas calcissilicáticas, queluzitos e quartzitos. O contato entre estas rochas está fortemente deformado por zonas de cisalhamento da fase Dn, assim como com as unidades do Complexo Santa Isabel. As estruturas dessa fase de deformação possivelmente refletem descolamentos intraestratais durante fases tangenciais de deformação. Além disso, pode indicar um caráter alóctone para a Sequência Metavulcanossedimentar Urandi com relação à sua encaixante, o Complexo Santa Isabel. Em virtude da intensidade da deformação intraestratal, feiçóes primárias, sedimentares ou ígneas que existissem nessas rochas, possivelmente estão fortemente obliteradas. Um bandamento metamórfico/deformacional encontra-se estruturado segundo a foliação Sn e este é o resultado de deformações e transposiçôes associadas ao metamorfismo da fácies anfibolito.

A fase $\mathrm{D}_{\mathrm{n}+1}$ estruturou dobras e zonas de cisalhamento sinistrais com orientação geral NE-SW e zonas de cisalhamento destrais com orientaçáo geral E-W. Essas estruturas destrais haviam sido anteriormente interpretadas por Bertholdo (1993) sob um campo de tensão segundo E-W a NW-SE. As zonas de cisalhamento cartografadas nesse trabalho são correlacionadas àquelas descritas por Medeiros et al. (2011) e Medeiros (2012). Segundo esses autores, essas estruturas truncam migmatitos diatexíticos e metatexíticos, possuindo idade mínima de 2,05 Ma e máxima de 2,09 Ma, tendo, portanto, idade Riaciana-Orosiriana. O campo de tensão associado à essas estruturas é semelhante ao que foi sugerido por Barbosa e Sabaté (2002) e, desta forma, sugere-se um retrabalhamento no Paleoproterozoico para essa porção do Bloco Gavião. Resultados semelhantes a esses vêm sendo obtidos por outros autores a leste da área da SMU, tais como os produzidos por Cruz et al. (2009, 2011) e Borges (2012). Na SMU, a presença de paragêneses mineralógicas constituídas por hornblenda/plagioclásio nos metabasaltos e grunerita/magnetita nas formaçóes ferríferas, aliado às feiçôes de recristalização do plagioclásio nas rochas metabasalticas, sugerem condiçôes metamórficas de fácies anfibolito médio para as fases $\mathrm{D}_{\mathrm{n}}$ e $\mathrm{D}_{\mathrm{n}+1}$, grau metamórfico médio, com temperaturas estimadas entre 550 e $650^{\circ} \mathrm{C}$ (Simpson 1985, Gapais 1989, Stünitz \& Fitz Gerald 1993, Fitz Gerald \& Stünitz 1993, Burcher \& Frey 2002, Burcher \& Grapes 2011).

As estruturas da fase $\mathrm{D}_{\mathrm{n}+2}$ estão relacionadas com campos de tensão WSW-ENE. De acordo com Cruz e Alkmim (2006) essas estruturas truncam rochas do Supergrupo São Francisco e possuem, por tanto, idade máxima de $900 \mathrm{Ma}$ (Babinski et al. 2012). Desta forma, a presença dessas estruturas, sugerem um retrabalhamento deformacional das rochas da SMU durante o Neoproterozoico e, dessa forma, propóe-se a exclusão dessa região do domínio tectônico do Cráton do São Francisco proposto por Almeida (1977) e a sua inclusão no domínio tectônico da porção setentrional do Orógeno Araçuaí (sensu Pedrosa Soares, Alkmim \& Noce, 2007 e Alkmim et al. 2007). A paragênese metamórfica em rochas máficas, constituída por quartzo, epidoto e clorita reflete temperaturas entre 350 e $550^{\circ} \mathrm{C}$ (Burcher \& Frey, 2002 e Burcher \& Grapes 2011). O significado dos veios de granada ainda não foi suficientemente esclarecido, mas as relaçôes microestruturais entre hornblenda e biotita sugerem aporte de potássio nas reaçôes metamórficas, 
que possivelmente está relacionado com intrusōes graníticas. Interpretação de evolução semelhante também foi realizada por Jesus (2011).

\section{CONCLUSÕES}

A partir do que foi apresentado, conclui-se que na SMU podem ser identificadas metavulcânicas máficas anfibolitizadas, metapelitos, rochas calcissilicáticas, queluzitos, quartzitos e formaçôes ferríferas bandadas (Itabiritos). O acervo estrutural é o resultado da atuação de três fases de deformação $\left(D_{n}, D_{n+1}\right.$ e $\left.D_{n+2}\right)$. O arcabouço dominante é marcado por dobras de três graus de hierarquia, sendo que a SMU encontra-se estruturada segundo uma sinforme assimétrica vergente para NW. Essa estrutura representa o flanco NW de uma megassinforme de primeira ordem que estrutura tanto a SMU quanto o Complexo Santa Isabel. Zonas de cisalhamento desenvolvidas sob campo de tensão E-W a NW-SE e WSW-ENE integram o arcabouço estrutural, estando associadas com as fases deformacionais $\mathrm{D}_{\mathrm{n}+1}$ " e $D_{n+2}$, respectivamente. Essas estruturas refletem, sucessivamente, retrabalhamento deformacional e metamórfico da SMU durante o Paleo e Neoproterozoico. Desta forma, sugere-se a revisão do limite do Cráton do São Francisco para essa região e a sua inserção no domínio tectônico setentrional do Orógeno Araçuaí.

A análise petrográfica levou a identificação de uma paragênese metamórfica progressiva sin- $\mathrm{D}_{\mathrm{n}}$ e $\sin -\mathrm{D}_{\mathrm{n}+1}$ da fácies anfibolito médio, com temperatura variando entre 550 e $650^{\circ} \mathrm{C}$, representada pela associação hornblenda, plagioclásio e clinopiroxênio nas rochas máficas e grunerita-cumingtonita nos itabiritos da SMU. Também foi verificada uma paragênese de alteraçáo hidrotermal sin- $\mathrm{D}_{\mathrm{n}+2}$ da fácies xisto verde, com temperatura estimada variando entre 350 e $500^{\circ} \mathrm{C}$.

\section{AGRADECIMENTOS}

Os autores querem expressar seus agradecimentos à Bahia Mineração pelo apoio aos trabalhos de campo. Também, gostariam de agradecer à Companhia Baiana de Pesquisa Mineral (CBPM) pela confecçáo das lâminas, e ao CNPq pela bolsa Produtividade em Pesquisa (Processo 307590/2009-7) de Simone C. P. Cruz e pelos recursos do projeto Edital Universal (Processo 473806/2010-0). Além disso, os autores são gratos aos revisores pelas cuidadosas observaçóes e contribuições.

\section{REFERÊNCIAS}

Alkmim F.F. \& Martins-Neto M.A. 2001. A Bacia Intracratônica do São Francisco: Arcabouço Estrutural e Cenários Evolutivos. In: C. P. Pinto \& M Martins-Neto (eds.) Bacia do São Francisco: Geologia e Recursos Naturais. Belo Horizonte, Sociedade Brasileira de Geologia - Núcleo Minas Gerais, p. 9-30.

Alkmim F.F., Brito Neves B.B., Alves J.A.C. 1993. Arcabouço tectônico do Cráton do São Francisco - uma revisão. In: J. M. Dominguez \& A. Misi (eds.) O Cráton do São Francisco. Salvador, SBG/ Núcleo BA/SE/SGM/CNPq, p. 45-62.

Alkmim F.F., Pedrosa-Soares A.C, Noce C.M., Cruz S.C.P. 2007. Sobre a Evolução Tectônica do Orógeno Araçuaí-Congo Ocidental. Geonomos, 15:25-43.

Almeida F.F. 1977. O Cráton do São Francisco. Revista Brasileira de Geociências, 4:349-364.

Arcanjo J.B., Marques-Martins A.A., Loureiro H.S.C., Varela P.H.L. 2005. Projeto Vale do Paramirim, Bahia: geologia e recursos minerais. Salvador, CBPM, Série arquivos abertos 22, 82 p.

Babinski M., Pedrosa-Soares A.C., Trindade R.I.F., Martins M., Noce C.M., Liu D. 2012. Neoproterozoic glacial deposits from the Araçuaí orogen, Brazil: age, provenance and correlations with the São Francisco craton and West Congo belt. Gondwana Research, 21:451-465

Barbosa J.S.F. \& Sabaté P. 2002. Geological features and the Paleoproterozoic collision of four Archean crustal segments of the São Francisco Craton, Bahia, Brazil. A synthesis. A syntesis. Anais da Academia Brasileira de Ciências, 74(2):343-359.

Barbosa O. \& Moutinho da Costa L.A. 1973. Projeto Leste do Tocantins/Oeste do São Francisco; Fase IV, II etapa de campo. Rio de Janeiro, CPRM/DNPM/PROSPEC, 8 v.

Barbosa, N. S. 2010. Geocronologia dos terrenos granito-greenstone da região de Riacho de Santana, Bahia. Dissertação de Mestrado, Instituto de Geociências, Universidade Federal da Bahia, 62 p.

Bertholdo A.L. 1993. Comportamento estrutural dos Supergrupo São Francisco e Espinhaço e do embasamento entre as serras do Espinhaço setentrional e as serras de Monte Alto (BA) e Central (MG). Dissertação de Mestrado, Instituto de Geociências, Universidade Federal do Rio de Janeiro, 87 p.

Borges J.O. 2008. Geologia do Distrito Manganesífero de UrandiLicinio de Almeida: Resultados Preliminares. Trabalho Final de Graduação, Instituto de Geociências, Universidade Federal da Bahia, 118 p.

Borges J.O. 2012. Geologia e Evolução Metalogenética das formações manganesíferas da Seqüência Metavulnossedimentar Licínio de Almeida: o exemplo da Mina de Lagoa Dantas, Caetité, Bahia. Dissertação de Mestrado, Geologia. Instituto de Geociências, Universidade Federal da Bahia, 250 p.

Brito-Neves B.B., Cordani U.G., Torquato J.R., 1980. Evolução geocronológica do Precambriano no estado da Bahia. In: H.A.D. 
Inda \& F.B. Duarte (eds.) Geologia e Recursos Minerais do Estado da Bahia, v. 3, Salvador: SME-COM, p. 1-101.

Bucher K. \& Frey M. (eds.) 2002. Petrogenesis of metamorphic rocks. Berlin, Springer-Verlag, 341 p.

Bucher K. \& Grapes R. (eds) 2011. Petrogenesis of metamorphic rocks. Berlin, Springer-Verlag, 441 p.

Cruz S.C.P. \& Alkmim F.F. 2006. The tectonic interaction between the Paramirim Aulacogen and the Araçuaí Belt, São Francisco Craton region, Easter Brazil. Anais da Academia Brasileira de Ciências, 1:151-173

Cruz S.C.P., Barbosa J.S.F., Alves E.S., Damasceno G.C., Machado G.S., Borges J.O., Gomes A.M., Mesquita L., Pimentel I., Leal A.B.M., Palmeira D.S. 2009. Mapeamento geológico e levantamentos de recursos minerais da Folha Caetité (Escala 1: 100.000), Relatório Final. Programa de Levantamentos Geológicos Básicos. Salvador, Convênio UFBA-CPRM-FAPEX, 175p

Cruz S.C.P., Barbosa J.S.F., Santos-Pinto M., Peucat J.J., Souza J.S. 2011. O magmatismo Riaciano-Orosiriano no Bloco Gavião, Cráton do São Francisco, Bahia: estágio atual de conhecimento e implicações tectônicas. In: SBG, $13^{\circ}$ Simp. Nac. Est. Tect., e 70 Intern. Symp. Tect., 2011. Campinas. Resumos expandidos. CD-ROM.

Fettes D \& Desmons J. 2007. Metamorphic Rocks: A Classification and Glossary of Terms: Recommendations of the International Union of Geological Sciences Subcommission on the Systematics of Metamorphic Rocks. Cambridge: Cambridge University Press. 244p.

Fernandes P.C.E.A., Montes M.L., Braz E.R.C., Montes A.S.L., Silva L.L., Oliveira F.L.L., Ghignone J.I., Siga Jr. O., Castro H.E.F. 1982 Geologia. In: Projeto Radambrasil. v. 29. Folha SD.23 Brasília. Rio de Janeiro, MME/SG, p. 25-204

Figueiredo B.S. 2009. Mapeamento Geológico e Análise Estrutural da Sequência Metavulcanossedimentar Urandi, Bahia. Trabalho Final de Graduação, Instituto de Geociências, Universidade Federal da Bahia, $135 \mathrm{p}$

Fitz Gerald J. D. \& Stünitz H. 1993. Deformation of granitoids at low metamorphic grade. I: Reactions and grain size reduction. Tectonophysics, 221(3-4):269-297.

Fleuty M. J. 1964. The descriptions of folds. Proceedings of the Geologists' Association, 75:461-492.

Gapais D. 1989. Shear structures within deformed granites: mechanical and thermal indicators. Geology, 17:1144-1147.

Guimarães J.T., Alkmim F.F., Cruz S.C.P. 2012. Supergrupos Espinhaço e São Francisco. In: J.S.F. Barbosa, J. Mascarenhas, J.M.L. Domingues, L.C Correa-Gomes. Geologia da Bahia. Pesquisa e Atualização de Dados. Salvador, CBPM.

Jardim de Sá E.F., Brito Neves B.B., McReath I., Bartels R.L. 1976. Novos dados geocronológicos sobre o Cráton do São Francisco no Estado da Bahia. In: SBG, $29^{\circ}$ Cong. Bras. Geol., 1976. Ouro Preto. Anais... p. 185-204.

Jesus S.S.G.P. 2011. Petrografia e análise microestrutural da zona de alteração hidrotermal na Sequência Metavulcanossedimentar Urandi: metamorfismo, evolução tectônica e implicações metalogenéticas. Trabalho final de Graduação, Instituto de Geociências, Universidade Federal da Bahia, 152 p.

Leahy G.A.S. 1997. Cartografia, Petrologia e Litogeoquímica da Intrusão de Ceraíma (Sudoeste da Bahia). Dissertação de Mestrado, Instituto de Geociências, Universidade Federal da Bahia, 140 p.

Loureiro H.S.C., Lima E.S., Macedo E.P., Silveira F.V., Bahiense I.C., Arcanjo J.B.A., Moraes-Filho J.C., Neves J.P., Guimarães J.T., Rodrigues L.T., Abram M.B., Santos R.A., Melo R.C. 2010. Geologia e Recursos Minerais da Parte norte do Corredor de Deformação do Paramirim: Projeto Barra-Oliveira dos Brejinhos. Salvador, CBPM, 118 p. il. Série Arquivos Abertos, 33.

Mascarenhas J.F. \& Garcia T.W. 1989. Texto explicativo do mapa geocronológico do Estado da Bahia. Salvador: SGM, 186 p.

Mascarenhas J.F. 1979. Evolução Geotectônica do Precambriano do Estado da Bahia. In: H.A.V. Inda (ed.) Geologia e Recursos Minerais do Estado da Bahia. Textos Básicos. v. 2. Salvador: SME/ CPM, p. 57-165.

Medeiros E.L.M. 2012. Geologia, Evolução Estrutural e Geocronologia do Complexo Santa Isabel na região de Urandi, Bahia. Dissertação de Mestrado, Instituto de Geociências, Universidade Federal da Bahia, 186 p.

Medeiros E.L.M., Cruz S.C.P., Barbosa J.S.F., Carneiro M.A., Jesus S.S.G.P., Armstrong R., Brito R., Delgado I. 2011. Ortognaisses migmatíticos do Complexo Santa Isabel na região de UrandiGuanambi, Bahia: análise estrutural, geocronologia e implicações tectônicas. In: SBG, $13^{\circ}$ Simp. Nac. Est. Tect. e $7^{\circ}$ Intern. Symp. Tect., 2011. Campinas. Resumos expandidos. CD-ROM.

Melo R.C. 1984. Projeto mapas metalogenéticos e de previsão de recursos minerais. Folha SD.23-Z-B, Guanambi, Escala 1:250.000. Volume I, textos e mapas. Salvador, CPRM, 36 p.

Moraes L.C., Martins A.B.M., Sampaio A.R., Gil C.A.A, Andrade Filho E.L., Arcanjo J.B., Lima R.C.C.L., Melo R.C., Oliveira R.B.A.O., Margalho R.S.F.X. 1980. Projeto Brumado-Caetité. Relatório Final, $1^{\text {a }}$ Fase. Salvador, CPRM/DNPM, v. 1, 463 p.

Moutinho da Costa L.A. \& Silva W.G. 1980. Projeto Santo Onofre. Relatório Final. Rio de Janeiro, DNPM/CPRM/TRISERVICE, 25 v.

Paim M.M., Conceição H., Rosa M.L.S., Cruz Filho B.E., Santos E.B., Peixoto A.A., Leahy G.A.S. 1998. Maciço de Cara Suja: Petrologia de uma intrusão tardia do Batólito Monzo-Sienítico GuanambiUrandi (Sudoeste da Bahia) e implicações geoquímicas para a gênese dos magmas sieníticos alcalinos-potássicos. In: $\mathrm{H}$. Conceição, M.J.M. Cruz, H.J.S. Sá, P. Sabaté (eds.) Contribuição ao Estudo dos Granitos e Rochas Correlatas. Salvador: Sociedade Brasileira de Geologia, Núcleo Bahia-Sergipe, p. 41-59.

Pedrosa-Soares A.C., Alkmim F.F., Noce C.M. 2007. Orógeno Araçuaí: Síntese do Conhecimento. 30 anos após Almeida 1977. Geonomos, 1:1-16.

Portela H.C.P., Marchetto C.M.L., Santos E.L., Menguissom G., Stein J.H., Moutinho da Costa L.A., Batista M.B., Messmann R., Silva W.G. 1976. Projeto Leste do Tocantins/Oeste do Rio São Francisco. Relatório Final, Fase V, Texto, v. 1a, 300 p.

Rosa M.L.S. 1999. Geologia, geocronologia, mineralogia, litogeoquímica e petrologia do Batólito Monzo-Sienítico Guanambi-Urandi (SW-Bahia). Tese de Doutorado, Instituto de Geociências, Universidade Federal da Bahia, 186 p.

Rosa M.L.S., Conceição H., Paim M.M., Santos E.B., Alves F.C. Leahy G.S., Leal L.R. 1996. Magmatismo potássico/ultrapotássico pós a tardi orogênico (associado a subducção) no oeste da Bahia: Batólito Monzo-Sienítico de Guanambi-Urandi e os sienitos de Correntina. Geochimica Brasiliensis, 10(1):27-42

Santos E.B. 1999. Petrologia dos Sienitos e Monzonitos Potássicos do Maciço do Estreito (SW-Bahia e NE-Minas Gerais. Dissertação de Mestrado, Instituto de Geociências, Universidade Federal da Bahia, 140 p.

Silveira W.P. \& Garrido I.A.A. 1998. Projeto Riacho de Santana. Relatório Final - Salvador: CBPM, 72 p.

Silveira W.P., Fróes J.R.B., Bastos Leal L.R. 1996. Geologia e potencial metalogenético do Greenstone Belt de Riacho de Santana. In: SBG, 41 Cong. Bras. Geol., 1996. Salvador. p. 109-112. 
Simpson C. 1985. Deformation of granitic rocks across the brittleductile transition. Journal of Structural Geology, 7(5):503-511.

Stünitz H. \& Fitz Gerald J.D. 1993. Deformation of granitoids at low metamorphic grade. II: Granular flow in albite-rich mylonites. Tectonophysics, 221(3-4):299-324.

Trendall A.F. 2002. The significance of iron-formation in the Precambrian stratigraphic record. International Association of Sedimentologists. Special Publication, 33:33-66.
Trendall a.f. \& Blockley J.G. 2004. Precambrian iron-formation. In: P.G. Eriksson, W. Altermann, D.R. Nelson, W.U. Mueller, O. Catuneanu (eds) The Precambrian Earth: tempos and events. Amsterdam: Elsevier, p. 403-421.

Twiss R.J. \& Moore E.M. (eds.) 2007. Structural Geology. Basingstoke: W. H. Freeman and Company, 736 p.

$\overline{\text { Arquivo digital disponível on-line no site www.sbgeo.org.br }}$ 